\title{
The influenza virus neuraminidase inhibitor produced by Staphylococcus aureus
}

\author{
S. L. Rybalko, A. V. Shapiro, L. D. Varbanets ${ }^{\text {}}$ \\ L. V. Gromashevski Kyiv Research Institute of Epidemiology and Infectious Diseases, Health Ministry of Ukraine \\ 4 Protasiv Yar vul., 01034, Kyiv, Ukraine \\ 1 Danylo K. Zabolotny Institute of Microbiology and Virology, National Academy of Sciences of Ukraine \\ 154 Zabolotnoho vul., 03143, Kyiv, Ukraine
}

\begin{abstract}
The glycoproteinic complex has been isolated from the Staphylococcus aureus culture fluid possessing an activity inhibiting influenza virus neuraminidase. Two fractions have been further purified containing different monosugars components, the first one has been shown to contain mannose, glucose, rhamnose, glucosamine, and galactosamine, while rhamnose is absent in the second fraction. A component of fraction 1 inhibits the neuraminidase activity and at the same time enhances the virus hemagglutinating activity more strongly comparing to the fraction 2. Some chemical madifications of the substances of the fractions studied (periodate oxidation, protease pretreatment, and delipidization) prove the carbohydrate component of the complex to be responsible for its antineuraminidase activity. The protease pretreatment decreases twice the antineuraminidase activity of the fraction 2 having no influence on this activity of the fraction 1.
\end{abstract}

Introduction. Enzymes of virions become one of the most attractive fields of scientific research during last two decades. The neuraminidase being an integrative part of orthomyxoviruses is among the best investigated viral enzymes. It participates in the cleavage of mucine layers and neuraminic acid residues from cell walls causing in such a way virus particles desaggregation. It is very probable that this enzyme prevents virions adsorption on mucines, a process of the great importance for influenza infection pathogenesis permitting virions to infect new sensitive cells.

So the neuraminidase inhibitors described become now especially interesting for a lot of research workers. A series of specific inhibitors being Nacetylneuraminic acid derivatives have been synthesized. Some data have been also published concerning isolation of inhibitors produced by bacteria and being glycoprotein substances [1].

We have isolated a neuraminidase inhibitor from $S$. aureus culture fluid. The aim of the present paper is to describe both this substance purification and the

(C) S. 1. RYRALKO, A. Y SHAPIRU, L. I) VARRANETS, 1999 data concerning its chemical properties, composition, and some biological characters.

Materials and Methods. Neuraminin-producing $S$. aureus strain and nutrient medium. The neuraminin preparations used in this investigation have been purified from the culture fluid of the $S$. aureus strain 392 , this strain having been isolated from a sputum sample of a patient with acute pneumonitis and deposited in the All-Union Antibiotics Research Institute (Moscow) in 1988. This strain is found to be sensible to lysis by phages belonging to the III phage group, 53/85 phagomosaic, and to the type 18 according to the Pillet classification.

For neuraminin isolation the culture medium used contained the following substances: enzymedigested peptone $(1.0 \pm 0.3 \%)$, lactose $(1.0 \pm 0.3 \%)$, yeast extract $(0.3 \pm 0.05 \%), \quad \mathrm{MgSO}_{4} \times 7 \mathrm{H}_{2} \mathrm{O}$ $(0.05 \pm 0.01 \%)$, and $0.15 \mathrm{M}$ phosphate buffer, $\mathrm{pH}$ of the medium being 7.2.

Isolation of neuraminidase inhibitor. The neuraminidase inhibitor has been obtaincd from the culture fluid using ethanol fractionation approach (30$50 \%$ ) and boiling during $10 \mathrm{~min}$ followed by gel filtration on the Sepharose $4 B$ columns $(2.2 \times 60 \mathrm{~cm})$ 
equilibrated with $0.1 \mathrm{M}$ ammonium acetate. In the fractions collected $(2.5 \mathrm{ml})$ the protein content has been determined according to Lowry et al. [2], the carbohydrates have been assessed using phenol and sulfuric acid approach [3]

Analytical methods. Analytical disk electrophoresis has been run in $5.6 \%$ polyacrylamide gel in the presence of $0.2 \%$ sodium laurylsulfate, the current being $5 \mathrm{~mA}$ per tube. The samples have been prepa-

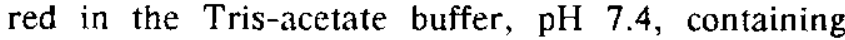
sodium laurylsulfate $(1 \%)$ and $\beta$-mercaptoethanol $(0.001 \%)$.

The process was usually stopped when the mar ker dye (bromephenol blue) formed a line situated at the distance about $1 \mathrm{~cm}$ from the lower edge of each tube. To detect the proteins separated, the gels have been stained using the Coomassie R-250 solution, the carbohydrates having been visualized by the Schiff reagent.

The molecular masses of the components separated have been calculated from the disk electrophoresis data [4] using several standard marker proteins - hexokinase, bovine serum albumin, and trypsin, their molecular masses being 96000, 68000, and $23000 \mathrm{Da}$, respectively.

Amino acids and hexosamines have been determined with the automatic amino acids analyzer KLA («Hitachi», Japan) after the hydrolysis in $6 \mathrm{~N} \mathrm{HCI}$ (20 hs, $110^{\circ} \mathrm{C}$ ).

Monosaccharides composition of our preparations has been determined after the acid hydrolysis (using $2 \mathrm{~N} \mathrm{HCI}$ treatment during 20 hs at $100^{\circ} \mathrm{C}$ ) by paper chromatography method in a solvent system containing butanol, pyridine, and water $(6: 4: 3)$; our developers were acidic phtalate-aniline, alkaline caustic silver, and alcoholic ninhydrin solutions [5]. Another method of monosaccharides determination was gasliquid chromatography permitting to obtain acetic polyol products with the «Chrom-5» device.

Sialic acids determination has been performed with resorcinol method $[5]$.

To determine fatty acids, the neuraminin inhibitor preparations have been hydrolyzed by $2 \mathrm{~N} \mathrm{HCl}$ (the acid is to be diluted by methanol) at $100{ }^{\circ} \mathrm{C}$ during 2 hs. The fatty acids have been then extracted by chloroform and analyzed at the «Zwiet-100» chromatograph.

The periodate oxidation of $S$. aureus neuraminin has been performed as follows. The aqueous neuraminin solution $(0.1 \%)$ has been added to $0.2 \mathrm{M}$ sodium periodate, the mixture has been kept at $5{ }^{\circ} \mathrm{C}$ during $72 \mathrm{hs}$, periodate excess being usually destroyed with ethylene glycol. The preparation dialyzed overnight has been then dried, treated with sodium borhydride, the excess of the last reagent being taken off using $\mathrm{KY}-2\left(\mathrm{H}^{+}\right)$resin, and lyophilized [5].

To separate phospholipids, the preparation has been treated by methanol $(1 \mathrm{ml}$ per $10 \mathrm{mg}$ of preparation) during $10 \mathrm{~min}$ at $55^{\circ} \mathrm{C}$. The mixture has been then cooled and treated with chloroform $(2 \mathrm{ml}$ per $10 \mathrm{mg}$ ), shaken overnight at $20{ }^{\circ} \mathrm{C}$ and centrifugated. Such a treatment has been repeated four times.

Some neuraminin modifications have been obtained using a proteolytic complex of wide specificity isolated from Bacillus mesentericus, the reaction being stopped by the protease inhibitor added to the mixture.

Virus strains. The following influenza virus strains have been used in this research: $4 / 1$, a highly immunogenic variant of $\mathrm{A} /$ Khabarovsk/77/H1N1 strain; $4 / 2$, a variant of the same strain possessing low immunogenity; $2 / 1$, a highly immunogenic variant of $\mathrm{A} /$ Victoria/ $75 / \mathrm{H} 3 \mathrm{~N} 2 ; 5 / 2$, a variant of this strain with low immunogenity; T5 and T14 strains isolated from mice lung tissues at the second and at the 14 th days of infection; strains 38 and 44 isolated from mice lung materials at the third month after infection; an isolate of the $\mathrm{A} / \mathrm{Kiev} / 6 / 84 / \mathrm{H} 3 \mathrm{~N} 2$ virus from a patient serum; a clinical isolate of the $\mathrm{A} / \mathrm{Le}-$ ningrad/13/85/H1N1 virus; $\mathrm{B} / \mathrm{Kiev} / / 1 / 84 /$ virus isolated from cerebrospinal fluid of a meningoencephalitis patient; $X-97$, a recombinant of $A /$ Lenin$\mathrm{grad} / 9 / 46 / \mathrm{Ho} /$ and A/Victoria/72 strains; A/Port-Chalmers/73/H3N2.

Study of biological activity. The antineuraminidase activity of preparations has been tested from the data concerning the inhibition of virus particles neuraminidase activity after the neuraminin treatment. The neuraminidase activity has been determined according to the Aminoff approach [6], the hemagglutinating activity of all the virus preparations being assessed after Gorbunova and Bokolova 17].

Results. As mentioned above the purification of neuraminidase inhibitor produced by $S$. aureus has been performed using the Sepharose $4 \mathrm{~B}$ gel filtration (Fig. 1); it is seen that we have successfully purified this product from some contaminating protein substances. The fractions $40-50$ have been further purified by centrifugation ( 4 hs at $144000 \mathrm{~g}$ ). The neuraminidase inhibiting activity has been detected in the supernatant material.

The results of our disk electrophoresis experiments have not permitted to detect any covalent protein-carbohydrate links because no protein line corresponding to carbohydrate substances mobility has been found. At the same time our gel filtration data also suggest there is no coincidence of protein and carbohydrate peaks, so the bacterial inhibitor is 


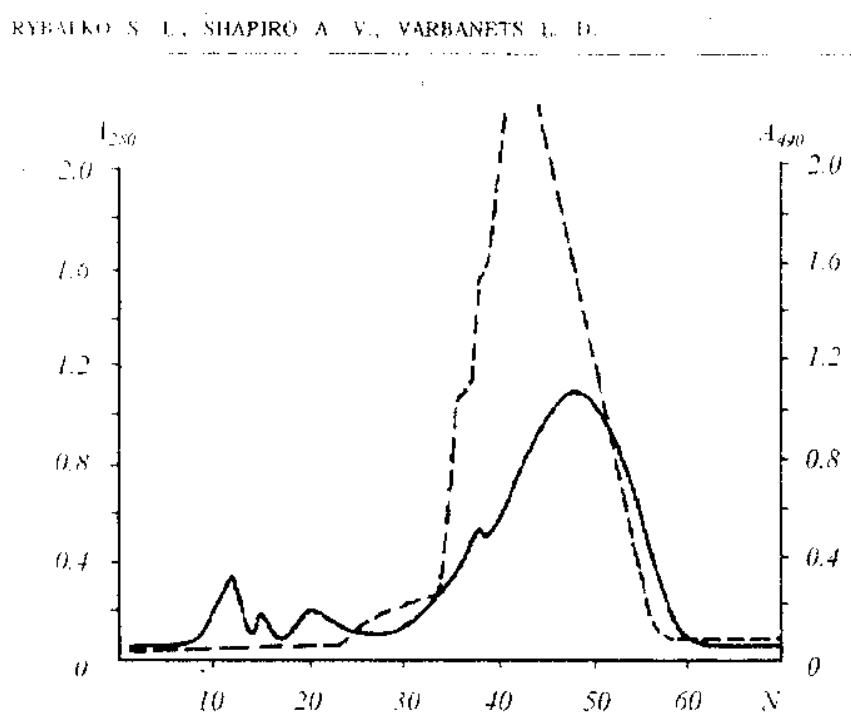

14g. I. Gef filtration of the neuraminidase inhibitor preparation on the Sepharose $4 \mathrm{~B}$ column. A solid line manifests the profein materal ehtiom. at douted one reflects the carbuhydrates efuton paltern

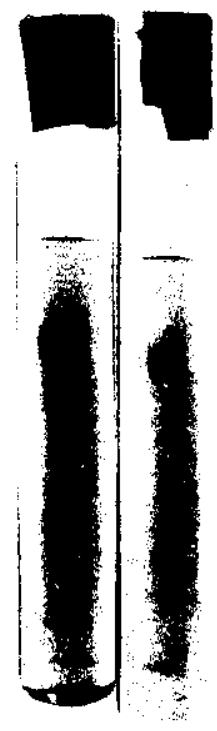

Fig. 2. Pulyactylamide ge! electrophoresis of the inhibitor preparatious staimed for carbohydrate defection

not proved to be a glycoprotein: it seems morc probably to be a glycoprotein complex (Fig. 2). Our study of the inhibitor chemical composition shows the presence of both protein and carbohydrate (1:10). Besides, the neuraminidase inhibitor of Staphylo coccus origin contains also falty acids carrying $11-20$ C-atons in their chains.
Table 1

Amino acid composition of the newrominidase inhibifor isoluted

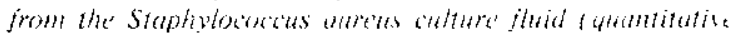
relations, ( $R$ )

\begin{tabular}{|c|c|c|c|}
\hline Amlme nat & $Q k$ & Alitt1.. $\quad 1,1,1$ & $\because R$ \\
\hline Aspartic atcid & 0.81 & isolestine & 0.48 \\
\hline Threonine & 1.31 & feucine: & 0.27 \\
\hline Serine & 0.40 & Tyrosine? & Traces \\
\hline Glutamic acid & 1.26 & Phomylatanine & 0.3 .5 \\
\hline Prolitis? & 0.16 & Jistidinte & laraces \\
\hline Glucine & 0.80 & lysinte & 0.51 \\
\hline Alanine & 1.12 & Arginint & $V_{0}$ \\
\hline Valine: & 0.42 & Methioming & Vraces \\
\hline
\end{tabular}

Our study of the inhibitor's amino acids content proves the presence of almost all of them with the only exception of arginine (see Table 1 ).

The deterninations concerning monosaccharides composition of neuraminidase inhibitor show mannose to be the main monosugar in this compound, glucosic content being rather poor; the ratio of these two neutral monosaccharides is $24: 1$ (Fig. 3, $a, b$ ). Additionally, we have also detected two hexosamines galactosamine and glucosamine, their relative contents being $1: 3.5$ (Fig. 4 ).

Sialic acid has not been found in the neuraminidase inhibitor preparations.

The specificity of inhibitory action of staphy/ococcus-produced substance and its effect on the influenzat virus neuraminidase activity have been studicd using different virus strains and isolates with different antigenic properties, the results reflecting the changes in the hemagglutinative and neuraminidase activities of virus preparations studied ( $T$ able 2). The Staphylococcus-produced neuraminin hals been shown to inhibit strongly the neuraminidase activity of all the influenza virus strains studicd hers. the level of inhibition being from 71 up to $94.4 \%$ (Table 2).

The gel filtration on the Sephadex $G-200$ column has separated two fractions of the bacterial inhibitor. fraction $I$ and fraction 2 (sce Fig. 5). The inves. tigation of their monosaccharides content has showll the substance in the fraction 2 to have monosugar composition identical with the original preparation. The substance in the fraction 1 has rather different 


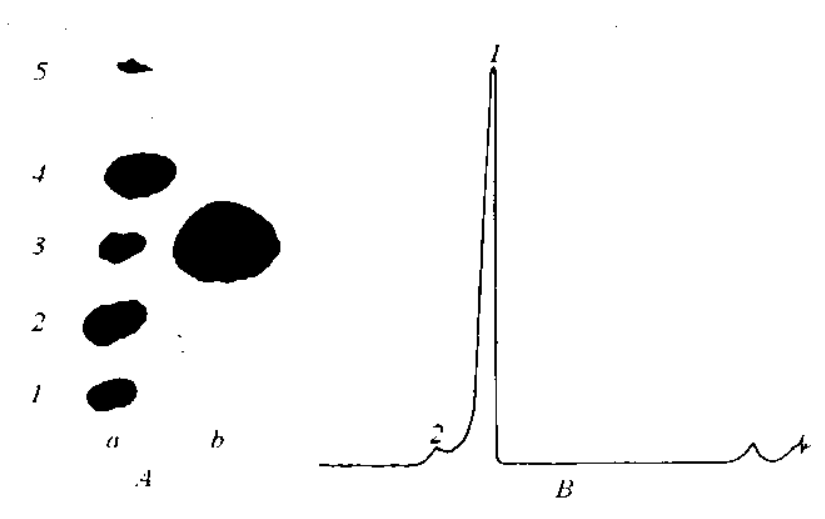

Fig. 3. Monosugars content of the neuraminidase inhibitor from $S$. aureus: $A-$ paper chromatography data $(a-$ control monosugars: 1 - galactose; 2 - glucose; 3 - mannose; 4 -xylose; 5 - rhamnose; $b$ - neuraminidase inhibitor (mannose)), $B-$ gas-fluid chromalography of the inhibitor preparations: $1-$ mannose; $2-$ glucose

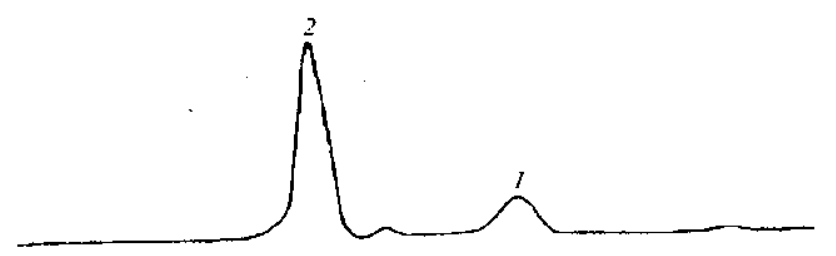

Fig. 4. Hexositmine content of the Staphylococcus-produced neuraminidase inhibitor: $l-$ galactosamine; $2-$ glucosamine

monosugars content because of rhamnose presence in addition to mannose and glucose, their relative content being 2:1.

The investigation of fractions effect on the neuraminidase and hemagglutinating activity of influenza virus strains (Table 3) shows the substance in the fraction 1 possesses higher antineuraminidase activity and simultaneously causes two-fold increase of the hemagglutinating activity comparing to the fraction 2 . To answer the questions concerning molecular components responsible for the activities mentioned above, we have modified the purified substances by periodate oxidation, proteases treatment, and delipidization process. These modifications are shown to influence

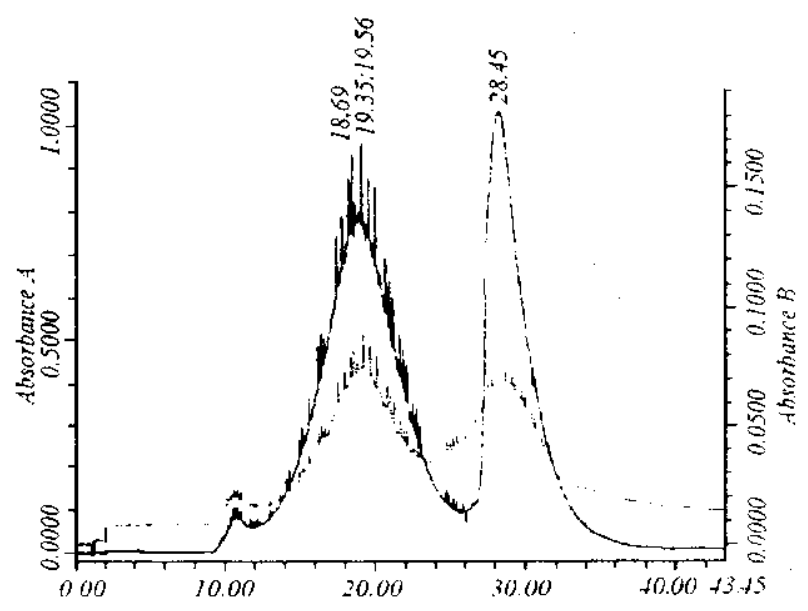

Fig. 5. Chromatography of the inhibitor preparation on the Sephadex G200 column

differently on the neuraminidase inhibitor activity (sec Table 3). The elimination of fatty acids has no effect on the antineuraminidase activity of the substance 1 and increases such activity of the substance 2 . The carbohydrate modification causes a total elimination of substances 1 and 2 antineuraminidase activities. The elimination of proteins has no effect on the antineuraminidase activity of the substance 1 but destroys, however, totally the same activity of the substance 2 . The delipidization procedures do not influence at all on the hemagglutinating activity of both substances; at the same time, the periodate oxidation as well as the use of the proteolytic complex cause the loss of the hemagglutinating activity.

Discussion. To our knowledge, the specific neuraminidase inhibitors described in the scientific literature and being both natural and synthesized substances may be attributed to two groups. The first one contains neuraminic acid analogues and derivatives, the second group contains the substances having no direct binding with any enzyme substrate or with its product. The Staphylococcus-produced inhibitor bclongs probably to the second group because of no sialic acids having been detected in this substance.

Comparative analysis of this inhibitor and also of the neuraminidase inhibiting substance isolated from Streptomyces [1] shows mannose and glucose to be the main neutral monosaccharides in both inhibitors, their ratios being, however, quite different. The Staphylococcus-produced inhibitor contains two aminosugars - glucosamine and galactosamine, the neu- 
RYBALKO S. L., SHAPIRO A. V., VARBANETS L. D.

Table 2

Effect of the Staphylococcous aureus produced neuraminidase inhibitor on the hemagglutinative and ne'uraminidase activity of influenza virus preparations

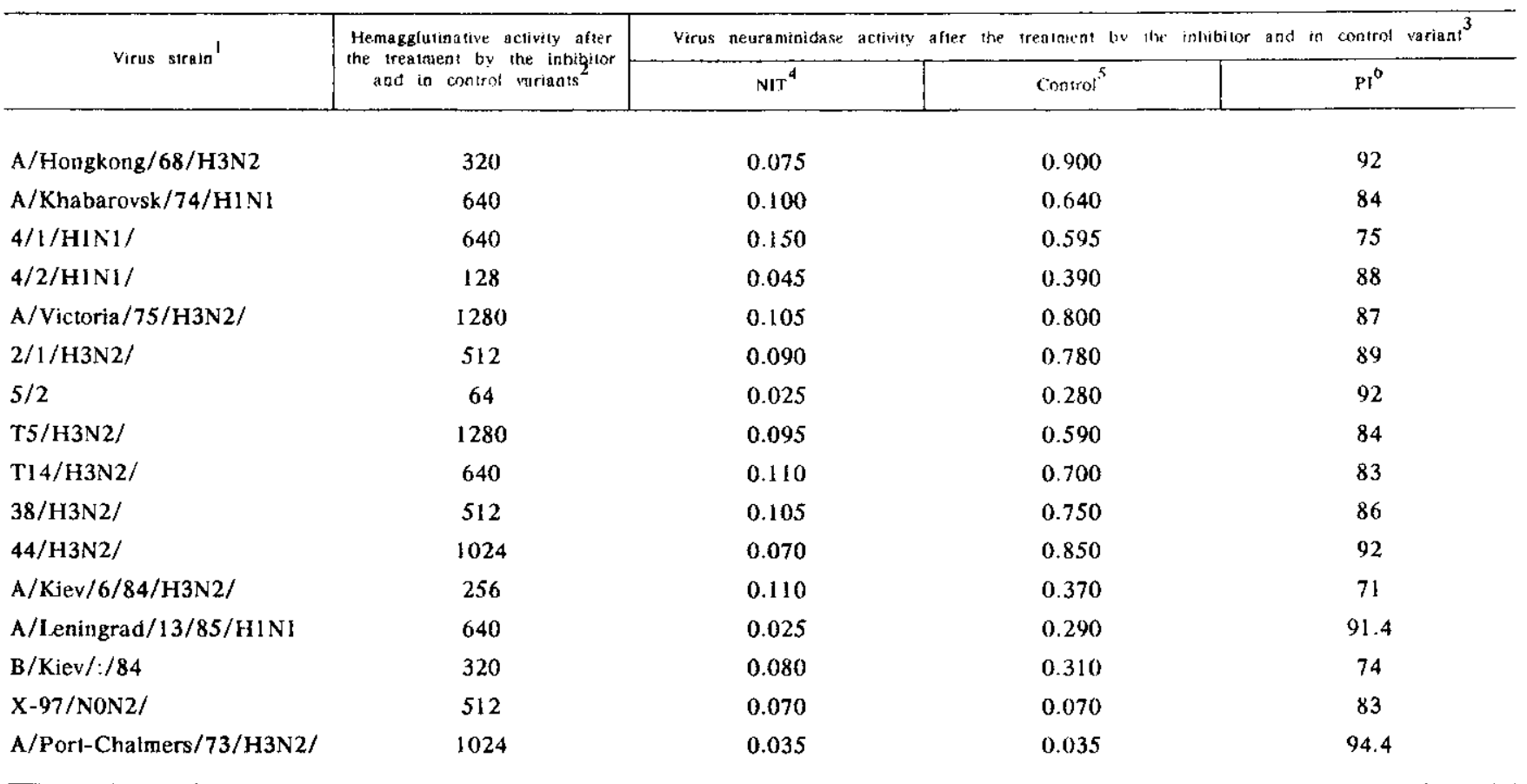

${ }^{1}$ Information concerning strains origin and some properties of these strains is given above (see «Malerials and Methods). ${ }^{2}$ Viral hemagglutinative activities are expressed as inverse values of hemagglutination titers. "Neuraminidase activities are given as optical density units at $549 \mathrm{~nm}\left(\mathrm{OD}_{549}\right) .{ }^{4} \mathrm{NIT}$ - virus samples are treated with neuraminidase inhibitor preparations. ${ }^{5} \mathrm{Control}-\mathrm{control}$ variants without inhibitor preparations. 6PI - per cent of inhibition after neuraminidase inhibitor treatment.

raminidase inhibiting substance isolated from Streptomyces contains only the first of them. No sialic acids has been found in both substances. Two inhibitors are also different in their amino acids content: the inhibitor of Staphylococcus origin contains methionine and no arginine. But the striking difference of these two substances is that, according to the data of Lin et al. [1], the Streptomyces-produced inhibitor is a glycoprotein.

Our results obtained with the disk electrophoresis approach show no covalent binding between protein and carbohydrate moieties in the neuraminin molecule because no line has been found corresponding to carbohydrate electrophoretic mobility; the gel filtration data on the Sepharose 4B column proving no coincidence of protein and carbohydrate peaks permit to conclude that the neuraminidase inhibitor isolated from $S$. aureus is not glycoprotein. Our point of view is that this inhibitor is more probably a glycolipoprotein complex.
The carbohydrate content of the Staphylococcus inhibitor including also its amino sugars resembles strongly influenza virus glycoproteins. Taking into consideration such a multicomponent patterns of inhibitor compounds - carbohydrates, proteins, and fatty acids - it would be of great interest to investigate the nature of the Staphylococcus neuraminin active group responsible for its antineuraminidase activity in our experiments with influenza virus preparations. To answer this question, two inhibitor preparations have been modified using periodate oxidation, proteolytic complex treatment, and delipidization. As a result we have found the inhibitory activities of preparations 1 and 2 to be different. The splitting of fatty acids has no effect on the antineuraminidase activity of the preparation $I$ and increases markedly such an activity of the preparation 2 . The carbohydrate modification eliminates totally neuraminidase inhibiting activity. The protein elimination has no effect on the antineuraminidase activity of the preparation 1 , but destroys 
THF, INFLUIENZ,A VIKUS NEURAMINIDASE. INHIBITOR

Table 3

Responsibility of different components of the neuraminiduse inhibitor isolated from Staphylococcus aurcus on the neuraminidase and on the inhibition of the hemagglutinative function found for the influenza virus A/Hongkong/68/H3N2/ strain

\begin{tabular}{|c|c|c|c|c|c|c|}
\hline \multirow{2}{*}{$\begin{array}{c}\text { Fraction and modifications of inhibitor } \\
\text { preparations }\end{array}$} & \multirow{2}{*}{$\begin{array}{l}\text { Neuraminidase inhibiting } \\
\text { nctivity, OD549 }\end{array}$} & \multicolumn{5}{|c|}{ Hemagglusinative netivily ascrease } \\
\hline & & PI & Hetnagglutination units/t. 2 nit & Multiplicity & y of & increase \\
\hline Total inhibitor preparation & 0.095 & 100 & 64 & & 0 & \\
\hline Fraction 1 & 01350 & 58 & 256 & & 4 & \\
\hline Fraction 2 & 0.200 & 44 & 128 & & 2 & \\
\hline Fraction 2 after delipidization & 0.0655 & 100 & 128 & & 2 & \\
\hline Fraction 1 after periodate oxidation & 0.390 & 0 & 64 & & 0 & \\
\hline Fraction 2 after periodate oxidation & 0.320 & 0 & 128 & ' & 0 & \\
\hline Fraction 1 after protease treatment & 0.85 & 100 & 64 & & 0 & \\
\hline Fraction 2 after protease treatment & 0.350 & 0 & 64 & & 0 & \\
\hline Protease effect on virus activities & 0.200 & 44 & 64 & & 0 & \\
\hline Control virus preparation & 0.370 & 0 & 64 & & 0 & \\
\hline
\end{tabular}

The $\mathrm{OD}_{549}$ values below 0.100 are thought to be negative.

completely such an activity of preparation 2 (see Table 3).

Berezin et al. [8] have studied the participation of carbohydrate moiety in the influenza virus neuraminidase activity; they have found that the elimination of the carbohydrate component of the viral enzyme with glycosidase does not change markedly the enzyme activity, i. e. this component has no effect on the enzymatic activity. Our results show the enzyme activity to be decreased during the viral neuraminidase interaction with the carbohydrate component of Staphylococcus preparation; the complete inhibitor inactivation has been observed after the carbohydrate modification by periodate oxidation. A similar mechanism of inhibitory action has been previously described for lectins - concanavalin A and phytohemagglutinin. These lectins are sensitive to the presence of glucose, mannose and sterically similar monosaccharide residues; so Lis and Sharon [9] and Rott [10] suppose that the interactions between lectins and the viral neuraminidase are realized due to the carbohydrate residues.

Because of the remarkable similarity of mono saccharides content in the influenza virus neuraminidase and in the Staphylococcus-produced enzyme inhibitor we postulate their interaction to be connected with the defense of the enzyme active center during its interaction with substrate molecules.

\section{С. Л. Рио̆алко, А. В. Wиніро, Л. Д. Rарбанеио}

Інгібітюр нейрамінідази вірусу грияу, що продукуеться золотистим стафілококом (Siaphylococcus aureus)

Резиме

3 культурального середовиия золотистого стасрілокока ( $S$.

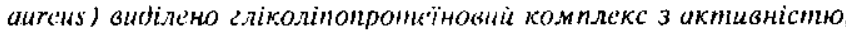
цо гальмує неирамініјазу арусу грипу. Очицено даі фракцї з різним вмістом моносахариоіз. Показано, ио дракиія I містинь манозу, глюкозу, рамнозу, слюкозамін та галактозамін; друга - всі иі моносахарида, крім рамнози. Реновина з фракцї̈ I zальмуе нейрамінідазну акпивність ма одночасно посилюе семаглютинативну актиеність вірусу значно сильніше, ніж реновина з фрикцї 2. Ряз хімінних модифікацій вив'ених ре'юзин (nерйојатне окислетия, обробка протеазою па делі-

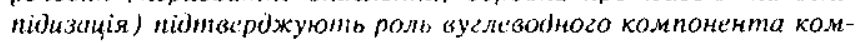

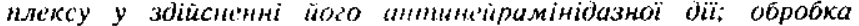
протеазою вовіті знажуе антинейрамінідазну активність фракцї̈ 2, не' внлизаю!и на таку жеканивність фракції 1.

\section{С. Л. рибалко, А. В. Uаниро, Л. Д. Bарбанеи}

Ингибитор нейраминидазы вируса гриппа, продуцируемый золотистым стафилококком (Staphy/ococcus aureus)

\section{Pezisme}

Из кульпуральнои среды S. аитаз выделен гликолипопротеиновый комплекс с активностью, ангиблрующсй нейраминидазную

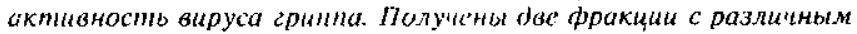
сод'ржанием моносахаридоя, перкая из которых вклюнает маннозу, слюкозу, рамнозу, глюказимин и салактозамин; вто-

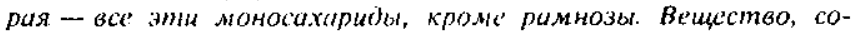

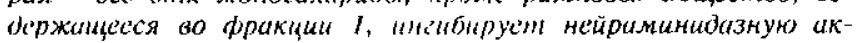


тивность и в то же время усиливаст семагдлюпинируюиую активность вируса гриппа знанительно более выраженно, чем вецество из фракции 2. Ряф химинеских модификаций изучаемых фракций (перйодатное окисление, обработка пропеазой и делипидизация) доказывает роль углевонного компонента комплекса в его антинейраминидазной активности; при эном обработка протеазой вдвое снижает антинейраминидазную активность фракции 2, не влияя на подобную акпивность фракции $l$.

\section{REFERENCES}

1. Lin W., Kunio $O$., Ko A. Isolation, purification and chemical properties of neuraminidase inhibitors N $289 / /$ Agricult. Biol. Chem. -1965.-39.-P. 923-930.

2. Lowry O. H., Rosenborough N. J., Farr A. L., Randall R. J. Protein measurement with the Folin reagent $/ / \mathrm{J}$. Biol. Chem.-1951.-193.-P. 265-275.

3. Dubois M., Gilles K., Hamilton, Rebers P. A., Smith F. Colorimetric method for determination of sugars and related substances // Analyt. Biochem.-1956.-28.-P. 350-353.

4. Fairbanks G., Stock $T$., Wallach $D$. Electrophoretic analysis of the major polypeptide of the human erythrocyte membrane // Biochemistry.-1971.-10.-P. 2606-2613.
5. Hay J. W., Lewis B. A., Simith F. Periodate oxidation of polysaccharides: general procedules // Meth. Carbohydrate Chem. - 1965. -5.-P. 357-361.

6. Aminoff $D$. Melhods for the quantitative estimation of $\mathrm{N}$ acetyl-neuraminic acid and their application to hydrolysates of sialomucoids // Biochem J.-1961.-8.-P. 384-392.

7. Gorbunova A. S., Sokolova M. I. Manual on laboratory diagnostics of influenza, parainflucnza and adenoviruses caused infections. - Moscow: Medghi $\angle, 1960-167 \mathrm{p}$.

8. Berczin V. E., Kolesnikov V. V., Kharitonenkov $I$. G. The role of carbohydrates in manifestation of the hemagglutinating and neuramividase activities of influenza viruses $/ /$ Vopr. Virusol. (Moscow) - - 1979.-N 6.-P. 624-631 (in Russian).

9. Lis $H$., Sharon $N$. The biochemistry of plant lectins (phytohemagglutinins) $/ /$ Ans. RLv. Biochem.-1973.-42.P. $541-574$.

10. Rott $R$. The structural basis of the function of influenza virus glycoproteins // Med. Microbiol. Immunol.-1977.-164.P. $23-33$.

УцК 579.861.2.222.19:5/8.282 Received 17.06.98 